\title{
Iontophoresis with Aqueous solution of Nirgundi (Vitex negundo, Linn.) in the Management of Pada Kantaka (Plantar Fasciitis) - A Case Report
}

\author{
Case Report
}

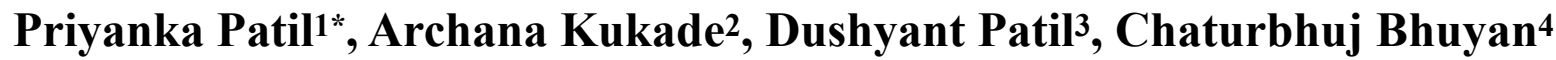

1. Assistant Professor (Ph.D Scholar), 2. Associate Professor, 3. Assistant Professor, 4. Professor \& Guide Dr. D. Y. Patil College of Ayurved and Research centre, Dr. D. Y. Patil Vidyapeeth, Pimpri, Pune.

\begin{abstract}
Vata kantaka is recognized as a Vatvyadhi. Walking bare-foot on uneven terrains causes vitiation of Vata which inturn causes pain which is specifically located at the heel of the foot. Vitiated Vata gets localized in Pada and it produces its characteristic symptom which is pricking pain like a thorn especially in the morning for first few steps, so as to be called as Vata kantak. Acharya Yogratnakar stated Vata kantaka as Pada kantaka. A 35 years old female patient visited Shalya tantra OPD with complaints of Right heel pain and diagnosed as Plantar fasciitis. 6 sittings of Iontophoresis with Nirgundi Aqueous extract were given on alternate day for 15-20 min. Pain on VAS was 7 before treatment. After treatment the score reduced to 0 . Nirgundi is well known for its analgesic, anti inflammatory, anti rheumatic property. Iontophoresis is a technique which improves the penetration of drug transdermally due to application of a low voltage current. So the iontophoresis with Nirgundi aqueos solution was found significantly effective in relieving symptoms of Pada kantaka i.e. Plantar fasciitis.
\end{abstract}

Key Words: Pada Kantaka, Plantar fasciitis, Vatvyadhi, Iontophoresis.

\section{Introduction}

Ayurveda postulates three main factors Vata, Pitta, and Kapha also known as Tridosha. Among tridosha, Vata is more vital because it controls Pitta and Kapha in order to accomplish various physiological functions(1). Owing to disrupting nature and challenging management Vata Vyadhi $\mathrm{h}$ a s b e e $\mathrm{n}$ included in Ashtamahagada(2). Pada kantaka is also primarily recognized as VataVyadhi.

It has been elaborately stated by Acharya Shushruta as walking bare-foot on uneven terrains causes vitiation of Vata which inturn causes pain which is specifically located at the heel of the foot. During the process of pathogenesis when the vitiated Vata gets localized in Pada, It produces its characteristic symptom which is pricking pain like a thorn, so as to be called as Vata kantak(3). Acharya Yogratnakar has stated Vata kantak as Pada kantaka. Acharya Sushruta has contributed detailed account of exhaustive range of both surgical and para-surgical procedures in various ailments. He has also mentioned Agnikarma in severe painful conditions of Twak, Mamsa, Sira, Snayu, Sandhi, Asthi due to vitiated Vata(4).

* Corresponding Author:

\section{Priyanka Patil}

Assistant Professor (Ph.D Scholar),

Dr. D. Y. Patil College of Ayurved and Research

Centre, Dr. D. Y. Patil Vidyapeeth, Pimpri,

Pune - 411018. India.

Email Id: priyankap044@gmail.com
Acharya Yogratnakar and Acharya Chakradutta has also indicated Agnikarma as therapeutic measure for Pada kantak(5).

Application of fatty material (Sneha), actual cauterization, massage, application of poultices and binding of ligatures should be the remedies where the aggravated Vayu would be found to have become involved in the Snayu (ligaments), joints and bones(6).

Acharya Sushruta has indicated Agnikarma for the treatment vata prakopa in sandhi, asthi and snayu(7). Thus Agnikarma can be efficiently employed as a therapeutic modality for Pada kantaka. The typical presentation of Plantar fasciitis is a history of intense sharp heel pain with the first couple of steps in the morning (8).It is the pain caused by degenerative irritation at the insertion of the plantar fascia on the medial process of the calcaneal tuberosity Initial conservative treatment of Plantar Fasciitis include a spectrum of modalities such as oral and local administration of NSAIDs and Stretching. When conservative treatment fails, treatment often progress to local infiltration of corticosteroids (Dexamethasone sodium phosphate $0.4 \%$ ) and if no relief is

afforded then surgical release of plantar fascia is the option(9).

With advancement of technology, Iontophoresis with $0.4 \%$ Dexamethasone solution became progressively popular replacing steroid injection. In some studies Iontophoresis with herbal medicine is shown a very encouraging result. In China, one study by Zhou Feng-hui; Zhao Ming-jie and Zhao Hai-yan of First Affiliated Hospital of Medical College of Jinan University, Guangzhou, China) has reported 100\% positive results by administration of traditional Chinese 
herbal medicine with the help of Iontophoresis for enhancement of bone healing(10). Vitex negundo Linn. (Verbenaceae), locally known as 'Nirgundi' is an important medicinal plant. As per Ayurvedic classics Nirgundi has Vata, Kapha, Shoth, Shoola pacifying properties. Its leaves are widely used externally for rheumatism and inflammations of joints. Aqueous extract of mature fresh leaves exhibit anti-inflammatory, analgesic and antihistamine properties(11). Therefore, Iontophoresis was employed to promote the absorption of aqueous solution of Nirgundi through plantar skin in the management of Plantar Fasciitis.

\section{Case report}

A 35-year-old female patient, not having history of any medical illness like DM, HTN, a housewife, with a history of long standing daily visited Shalya tantra Outpatient Department with the complaint of right heel pain for last 1 year.

\section{Clinical findings}

Patient came with preliminary complaint of pain while walking in the morning for first few steps. There was no history any sort of trauma. She consulted a physician and took treatment for 6 months. After that, She was managed with NSAIDs, steroid injections but the relief was for short duration. On general examination, the patient was hemodynamically stable, pulse rate $-70 / \mathrm{min}$ regular with normal volume and blood pressure $-110 / 70 \mathrm{mmHg}$ in sitting position. On local examination, range of right ankle joint movement in passive dorsiflexion was within normal limit but pain was there in sole region on passive dorsiflexion. Passive extension of the first metatarsophalangeal joint produced pain along the course of plantar aponeurosis. Severe tenderness elicited at medial aspect of the right heel at the level of calcaneal tuberosity.

\section{Diagnostic focus and assessment}

As per the Visual Analogue Score (VAS), the pain was scored as 7 and tenderness was graded as 3 which means severe pain on touch. No bony abnormality like calcaneal spur or fracture was evident on X-ray of the right foot calcaneal view. Serum uric acid was also within normal limit. Based on these findings, the condition was diagnosed as plantar fasciitis/ Pada kantaka and planned to manage by iontophoresis with Nirgundi aqueous extract.

\section{Therapeutic focus and assessment}

After obtaining written informed consent, the patient was advised for iontophoresis with Nirgundi aqueous extract. [Table 1]. Aqueous extract of Nirgundi was prepared at Sudhatatva Pharmacy of Dr. D. Y. Patil college of Ayurved And Research centre, Pimpri, Pune after authentication and standardization was done.

No oral medications or other therapies were administrated during the treatment period. Freshly prepared Aqueous extract approx $100 \mathrm{ml}$ was filled in each iontophoresis chamber and the patient was advised to keep his both feet separately in each of the chambers. A weak galvanic current was applied through the iontophoresis machine in anode mode starting from $0.00 \mathrm{mAmp}$ and gradually increased up to $04.0 \mathrm{mAmp}$. At this point, she felt a maximum tingling sensation in the foot region and current of $04.0 \mathrm{mAmp}$ was allowed to flow for $15 \mathrm{~min}$. Thereafter, $04.0 \mathrm{mAmp}$ current was allowed to flow in the cathode mode for 15 min for the same foot [Figures 1 and 2]. Similar such six sittings on alternate day were given. During the procedure, all metal ornaments were removed and all wires and foot plates were checked. During the course of treatment, she was advised to avoid prolonged weight bearing and use of silicon heel was encouraged.

\section{Follow-up and outcome of the therapy}

Significant reduction in the severity of pain was observed after the fourth sitting and the pain was almost relieved by the sixth sitting. The pain on VAS was reduced from 7 to 1 [Graph 1]. No tenderness at medial aspect of the right heel was complained by the patient. After treatment, the patient was followed for three months. No signs and symptoms of plantar fasciitis were reported even after three months of follow-up.

\section{Table 1: Properties of Nirgundi (Vitex negundo, Linn.)}

\begin{tabular}{|l|l|l|l|l|l|}
\hline Taste & Characteristics & Potency & Vipak & Function & Properties \\
\hline Bitter, Pungent & Light, dry & Hot potency & Pungent & Shulahara & Analgesic, Anti inflammatory \\
\hline
\end{tabular}

Table 2: Timeline

\begin{tabular}{|l|l|l|} 
Day & Clinical findings & Intervention \\
2 March 2020 & $\begin{array}{l}\text { Severe Pain at right heel for first few steps in the } \\
\text { morning since 1 year, tenderness at calcaneal } \\
\text { tuberosity, VAS score - 7, tenderness grade 3 }\end{array}$ & $\begin{array}{l}\text { First sitting of plantar iontophoresis with Nirgundi } \\
\text { aqueous extract for 15 min for each electrode. }\end{array}$ \\
\hline 4 March 2020 & Same as first day & $\begin{array}{l}\text { Second sitting of plantar iontophoresis with } \\
\text { Nirgundi aqueous extract for 15 min for each } \\
\text { electrode }\end{array}$ \\
\hline 8 March 2020 & $\begin{array}{l}\text { Pain for firs few steps in the morning but mild in } \\
\text { severity, VAS score- 5, tenderness grade 2 }\end{array}$ & $\begin{array}{l}\text { Third sitting of plantar iontophoresis with Nirgundi } \\
\text { aqueous extract for 15 min for each electrode }\end{array}$ \\
\hline Significant relief in pain, VAS score- 3 and & $\begin{array}{l}\text { Fourth sitting of plantar iontophoresis with Nirgundi } \\
\text { aqueous extract for 15 min for each electrode. }\end{array}$
\end{tabular}


10 March 2020

12 March 2020
Very negligible discomfort while walking in the morning, VAS score- 2

Got complete relief in pain and tenderness, VAS score -1
Fifth sitting of plantar iontophoresis with Nirgundi aqueous extract for $15 \mathrm{~min}$ for each electrode.

Sixth sitting of plantar iontophoresis with Nirgundi aqueous extract for $15 \mathrm{~min}$ for each electrode.

\section{Graph 1 - Improvement in tenderness and VAS score after each sitting}

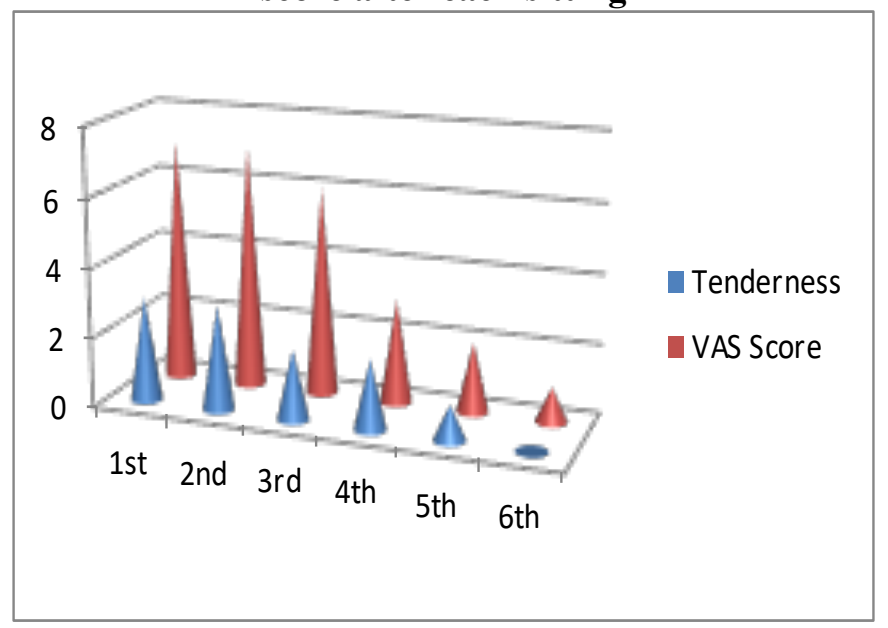

( $\mathrm{X}$ axis- sitting Day, $\mathrm{Y}$ axis- Gradation of tenderness and VAS on $0^{\text {th }}$ day and $11^{\text {th }}$ day)

Figure 1- Foot plates filled with Nirgundi Aqueous extract and iontophoresis in process

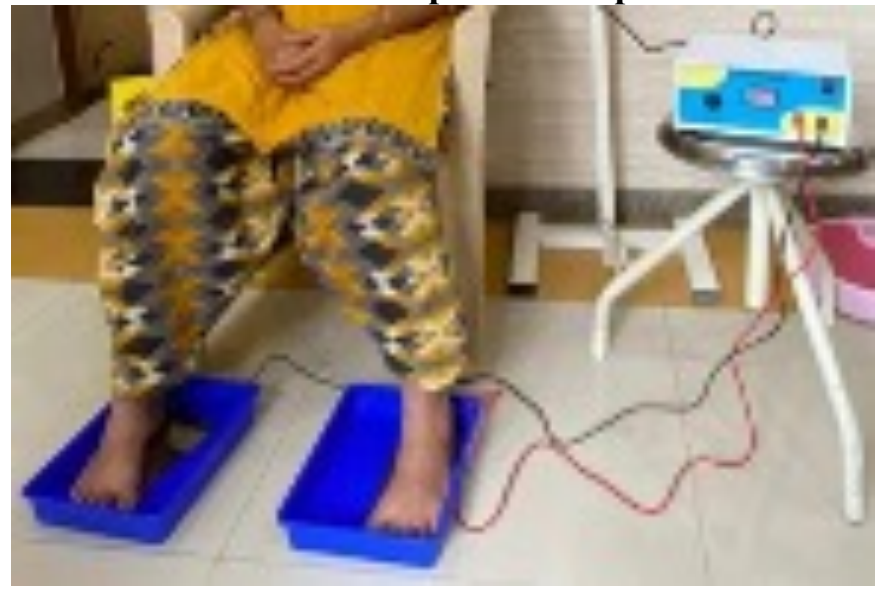

Figure 2- Prepared Aqueous extract of Nirgundi

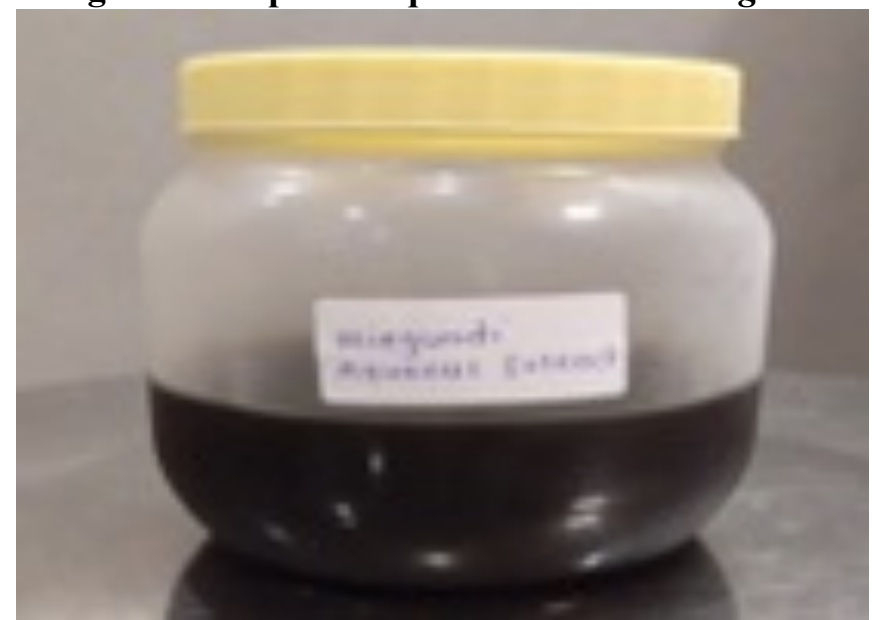

\section{Discussion}

Pada kantak is characterized by pain "just like pricked by thorn (kantak)" in the foot (Pada) and hence the name "Pada kantak". Severe pain (Rujah) as a result of localization of the vitiated vata dosha in differrent dushyas. As per the textual references, the features of Pada kantak can be accurately paralleled with Plantar fasciitis. Plantar Fasciitis is a degenerative disease of

plantar fascia precipitated by some factors like over stress (long standing, long walking), obesity, walking on hard surface and faulty shoes.Available treatment modalities according to Ayurveda and modern science are mentioned before among that Iontophoresis is also one of the treatment modalities for Plantar Fasciitis. It is a process in which ions in the therapeutic solution are transferred through the intact skin via electrical potential using bipolar electrodes.

Ample references are available regarding the oral as well as topical use of Nirgundi as an analgesic, anti-inflammatory measure without any major side effects. So, Plantar iontophoresis with aqueous solution of Nirgundi has been studied in the management of Pada kantak. The active ingredients of Nirgundi, permeate through intact skin of the sole and reach the plantar fascia. Plantar fascia being fibrous tissue with limited blood perfusion retains the drug for a relatively longer time. This might explain the anti-inflammatory, analgesic effect of aqueous solution of Nirgundi, in an efficient way in plantar fasciitis. Luteolin and apigenin and other active principles present in aqueous solution of Nirgundi, prevent cytokine induced cell damage. The COX-2-inhibitory activity of Nirgundi may explain in part its anti-inflammatory activity in Plantar Fasciitis. Moreover,flavonoids such as luteolin and apigenin in Nirgundi possess anti-inflammatory and anti-arthritic activity(12).flavonoids can penetrate the human $\operatorname{skin}(13)$.

This explains mode of action of iontophoresis with Nirgundi aqueous extract in the management of Pada kantaka (Plantar fasciitis).

\section{Conclusion}

On the basis of this single case study, it can be concluded that, iontophoresis with aqueous extract of Nirgundi is effective in Pada kantaka as Nirgundi has its Vata, Kapha, Shoth, Shoola pacifying properties. Its leaves are widely used externally for rheumatism and inflammations of joints. Aqueous extract of mature fresh leaves exhibit anti-inflammatory, analgesic and antihistaminic property.

Iontophoresis might improve absorption of active ingredients of Nirgundi like flavonoids which are studied for their antiinflamatory property and which is proven for its human skin penetration. Thus there is a 

wide scope for further detail study on number of patients clinically with appropriate data analysis for generalization of the results.

\section{References}

1. Mishra, L., Singh, B.B., and Dagenais, S. Ayurveda: A historical perspective and principles of the traditional healthcare system in India, Altern. Ther. Health Med., (2001); 7(2), 36-42.

2. Vaidya Yadavji Trikamji Acharya, Susrut Samhita with Nibandhasangraha commentary of Dalhan, Chaukhambha Sanskrit Sansthan, Reprint edition 2009, SutraSthan 33/4-5, Page no. 134

3. Vaidya Yadavji Trikamji Acharya, Susrut Samhita with Nibandhasangraha commentary of Dalhan, Chaukhambha Sanskrit Sansthan, Reprint edition 2009, Nidan Sthan 1/79, Page no. 164

4. Ambika dutta Shastri, Sushruta Samhita, Edited with Ayurveda Tattva Sandipika Hindi Commentaryby Kaviraj, Chaukhamba publications, Varanasi, Edition:Reprint 2007, Part 1, Sushruta Sutrasthan Chapter 12, Shloka 10.

5. Yogratnakar, Vaidyaprabha Hindi Commentary Edited by Dr. Indradev Tripathi,1998, Purvakhand Vatavyadhi Chikitsa, Page no. 524.

6. Vaidya Yadavji Trikamji Acharya, Susrut Samhita with Nibandhasangraha commentary of Dalhan, Chaukhambha Sanskrit Sansthan, Reprint edition 2009, ChikitsaSthan 8/4, Page no. 574
7. Sushruta Samhita, Edited with Ayurveda Tattva Sandipika Hindi Commentaryby Kaviraj Ambika dutta Shastri, Chaukhamba publications, Varanasi, Edition:Reprint 2007, Part 1, Sushruta Chikitsasthan Chapter 4 , Shloka 8.

8. Young CC, Rutherford DS, Niedfeldt MW. Treatment of plantar fasciitis.Am Fam Physician. $2001 \mathrm{Feb} 1.63(3): 467-74,477-8$.

9. Perelman GK, Figura MA, Sandberg NS: The medial instep Plantarfasciotomy. J foot Ankle Surgery 34: 447-457,1995.

10. Di Yi Jun Yi Da Xue Xue Bao(Acaedemic Journal of the first Medical college of PLA). PMID: 15201098, 2004 Jun;24(6):708-10.

11. Dharmasiri MG, Jayakody JRAC, Galhena G, Liyanage SSP, and Ratnasooriya WD. 2003.Anti-infl ammatory and analgesic activities of mature fresh leaves of Vitex J negundo. Journal of Ethnopharmacology 87(23):199 2003 August ; 87(2-3): 199-206; doi 10.1016/s0378-8741(03) 00159-4

12. Bansod and Harle, Vitex Negundo: Phytochemical constituents, traditional use and Pharmacological properties: Comprehensive review; Pharmacologyonline1:286-302(2009) Newsletter, Page no.- 286-302

13. Seelinger G, Merfort I, Wolfle U, Schempp CM.; Anticancerogenic effects of the Flavonoid Leutiolin. Molecules. 2008 Oct 22;13(10):2628-51. Doi:10.3390/molecules13102628 PMID:18946424; PMCID:PMC6245397. 